\title{
Mansoor IBN elyas shirazi: the exact retrospective of the anatomy of women in Iranian medicine
}

\begin{abstract}
One of the great physicians in medicine, surgery and pharmacy, is Mansur Ibn Elyas Shirazi, who is one of the fifteenth-century physicians in Shiraz, is remembered in two books titled Kifāyah-i Mujaihidīyah and Tashrihi Mansuri. Most of his reputation was in the knowledge of anatomy, pharmacology and medicine. Ibn Elias, for the first time in the Islamic world and civilization, has traced accurately anatomical pictures, and also brought together archeological discussions of the womb and fetus in the field of women's descriptions. In the book, Mujaheedih, he has provided extensive discussions on medicine and pharmacology. In this research, we review the biography and introduction of works and review the book of Tashrihi Mansuri's Aesthetics in the field of aesthetics.
\end{abstract}

Keywords: mansur ibn elyas shirazi, women's anatomy, anatomical illustration, tashrihi mansuri, persian medicin
Volume 4 Issue 4 - 2017

\author{
Seyyed Alireza Golshani,' Ehsan Golshan² \\ 'Department of History, Shiraz University of Medical Sciences, \\ Iran \\ 2MA Department of Foreign Languages, Marvdasht Azad \\ University, Iran
}

\begin{abstract}
Correspondence: Seyyed Alireza Golshani, Department of History, Faculty of Literature and Humanities, Ferdowsi University of Mashhad, Mashhad, Iran, Research Office for the History of Persian Medicine, Shiraz University of Medical Sciences, Shiraz, Iran, Email golshani_22@yahoo.com
\end{abstract}

Received: October 25, 2017 | Published: November 27, 2017

\section{Introduction}

Shiraz in southern of Iran, has been one of the centers of science and research in medical sciences from the 8 th to the 19th centuries. It has a reputation for being the origin and home of famous doctors and academics, schools, libraries and hospitals. Those who studied in this city would often rise to become rulers or prominent in the court of rulers in India, Transoxania and Ottoman. ${ }^{1}$

One of the Shirazian families that have been outstanding in the medical science, is the Elyasi family. This family lived in Persia from the Atabakan Seligori period from the thirteenth to the Qajar period in the nineteenth century. One of the largest physicians of this family is Mansur ibn Elias Shirazi, studied the history of medical and anatomical practices.

\section{Mansoor ibn elyas shirazi}

Mansur ibn Elyas Shirazi (1380-1422 AD) is a well-known Iranian physician, surgeon and pharmacologist who was born in Shiraz of southern Iran, during one of the Persian dynasties.

He wrote a book on medicine entitled Shah Shoja Mozaffari, son of Zine al-Abedin, "Kifāyah-i Mujāhidīyah" or Kifäyah-i Mansuri. The book consists of two parts: the first deals with of the theoretical and practical aspects of medicine and the second deals with the subject of citrus spices. ${ }^{2}$

From this physician, a book titled Tashrihi Mansuri (Persian language) has survived in Persia, which was presented to the governor of the Persian Gurkani, Pir Muhammad ibn Jahangir (c. 1374 - 22 February 1407), with the names of the Enlightenment. (Tashrh-i belTasvir), Tashṛ̣-i badan-i insān, Sharh al-Badan and Resaleh fi elm Tashrīh are also known and have one introduction and five chapters In the description of bones and nerves, muscles and vessels. This book, according to the Algod, is the first work by Muslims to describe the body with images, and since the author of this work has repeatedly referred to Ibn-nafis, it was probably be written after 1288 AD. ${ }^{3,4}$

Until $1290 \mathrm{AD}$, no book of anatomical books was written in the Muslim world. The author of the 14th and 15th century physician and scholar in Shiraz, contemporary to Hafez (1315-1390), was a great Iranian poet and scientist. The book also included the most detailed and most detailed aesthetic images of the anatomy of the anatomy of the time. One of the important features of the book is the six images associated with the book's articles, with three images of women and the uterus and embryos (Figures 1-3). ${ }^{3,4}$

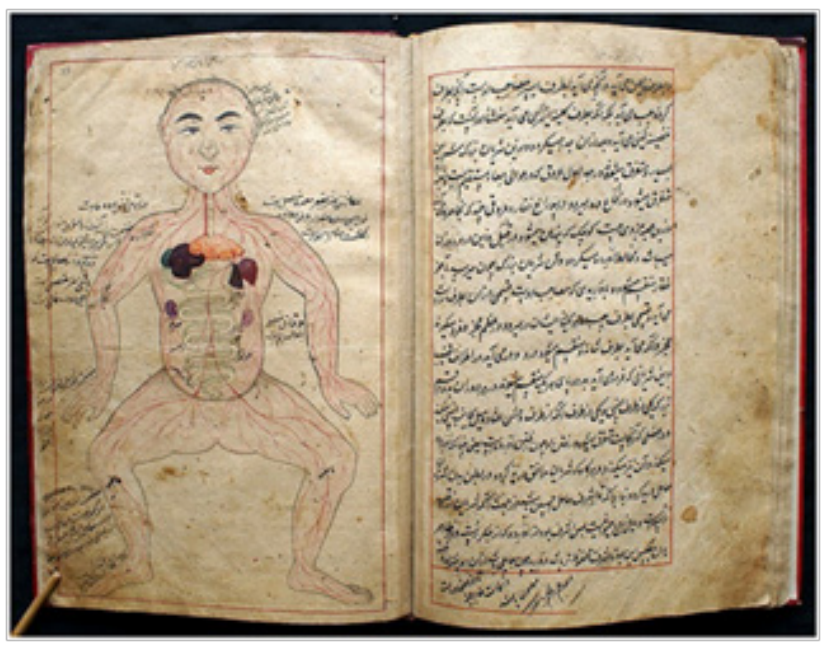

Figure I The illustration of human nerves from Tashrihi Mansuri. 


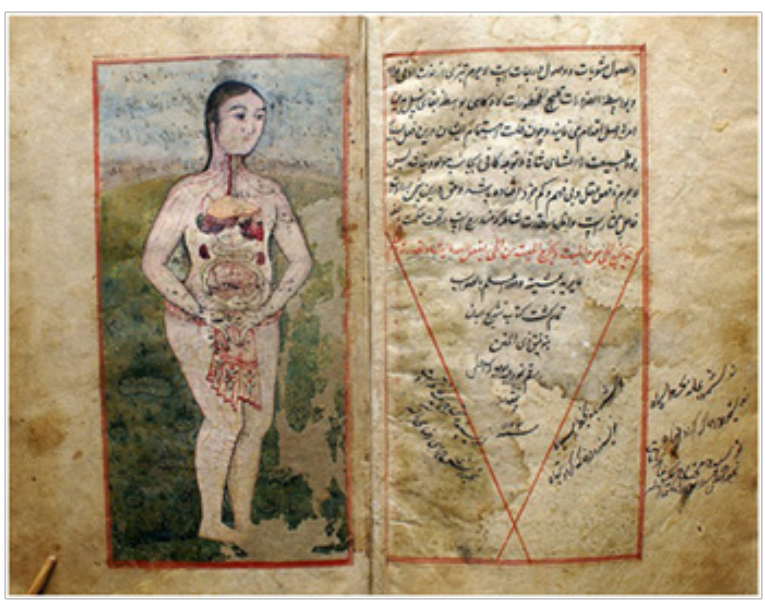

Figure 2 Illustration of Fetus and Heart, Lung and Kidney from Tashrihi Mansuri.

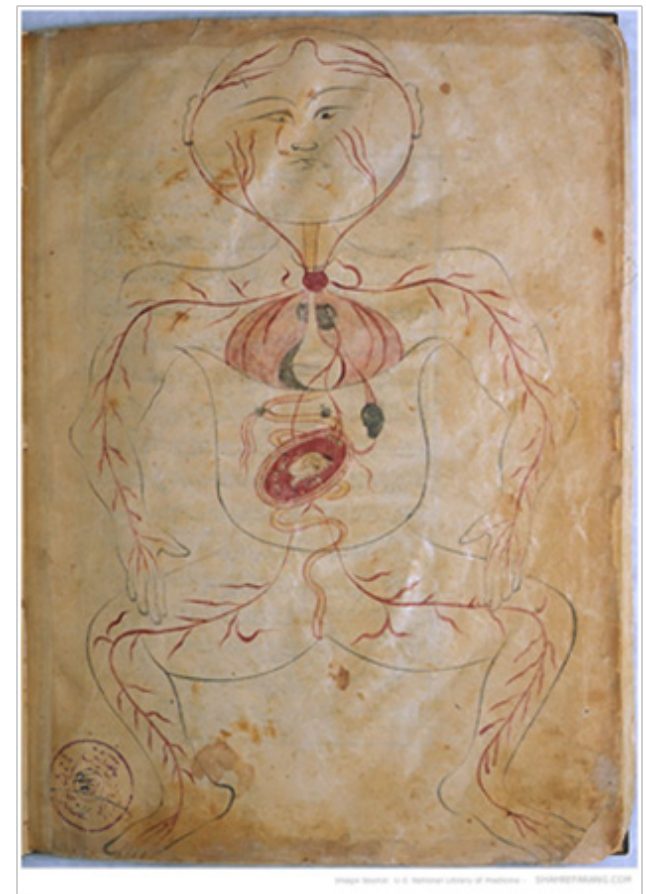

Figure 3 The illustration of Fetus and human nerves from Tashrihi Mansuri.
The influence of Mansoor's description can be clearly shown in other works of great anatomists such as:

Leonardo da Vinci (15 April 1452 - 2 May 1519), Andreas Vesalius (31 December 1514 - 15 October 1564) and Shirvani (? -1632) Tashrih-i badan Sharwani saw a doctor at the Ottoman court. Mansoor's descriptions from 1848, later, have been published for many years in India for the sake of scientific authority in the knowledge of theology.

\section{Conclusion}

One of the Iranian physicians and anatomists who for the first time in the world of science has referred to the topic of anatomy of women illustrated in his book is Mansur Ibn Elyas in Iran. Through this book, he helped to address the issue that had long been the result of religious problems, and helped the world of science with the help of women's anatomy images for the first time. He also has many scientific achievements in medicine and pharmacology.

\section{Acknowledgements}

None.

\section{Conflict of interest}

Author declares that there is no conflict of interest.

\section{References}

1. Golshani SA, Foruzani SA, Ghafouri Z, et al. Shiraz medical doctrine from al-bouyeh period to beginning of safavid dynasty. JIITM. 2012;3(3):341-350.

2. Kurmukov AG, Akimaliev AA. A short history of medicinal plant use in central asia. Medicinal Plants of Central Asia: Uzbekistan and Kyrgyzstan. 2013. p. 9-12.

3. Elgood C. A Medical History of Persia and the Eastern Caliphaterom the earliest time until the year A. D. 1932.|'London: The Cambridge University Press; $1951.347 \mathrm{p}$.

4. Savage Smith E. Anatomical Illustration in Arabic Manuscripts. Arab Painting, Brill, Leiden, Netherland; 2007. p. 147-159.

5. Zarshenas MM, Zargaran A, Mehdizadeh A, et al. Mansur ibn Ilyas (1380-1422 AD): A Persian anatomist and his book of anatomy, Tashrih-i Mansuri. J Med Biogr. 2016;24(1):67-71. 